\title{
How much to invest in glycemic control of a patient with diabetes mellitus type 2? A constant dilemma for the Brazilian Public Health System (SUS)
}

\author{
Ana Carolina de Oliveira Gonçalves ${ }^{1}$, Maurilio de Souza Cazarim², Cristina Sanches ${ }^{1}$, \\ Leonardo Régis Leira Pereira ${ }^{2}$, André de Oliveira Baldoni ${ }^{1}$
}

\begin{abstract}
${ }^{1}$ Midwest Campus Dona Lindu, Faculty of Pharmacy, Federal University of São João Del-Rei (UFSJ), Divinópolis, Brazil, ${ }^{2}$ Faculty of Pharmaceutical Sciences of Ribeirão Preto, University of São Paulo, Ribeirão Preto, Brazil
\end{abstract}

\begin{abstract}
Diabetes mellitus type 2 (DM2) affects millions of people worldwide and causes several complications for the patient, consuming large sums of financial resources from the health services. This study aims to estimate the financial investment of DM2 treatment for glycemic control of the patient, from the point of view of the municipal Public Health System (SUS). The Delphi technique was used to validate the opinion of a team of judges, specialists in DM2, and health service managers, on the investment necessary for glycemic control of patients with DM2 through the application of questionnaires. In order for the patient to achieve glycated hemoglobin (A1c) $<7 \%$, an investment of US $\$ 2,419.06$ (value/patient/year) is necessary. As the value of A1c increases, investment is reduced. This result reveals the intention to allocate resources for the prevention of DM2 and its complications.
\end{abstract}

Keywords: Diabetes mellitus. Pharmacoeconomics. Health care cost.

\section{INTRODUCTION}

Diabetes mellitus (DM) is a multifactorial metabolic disorder (ADA, 2016) that affects about 415 million people worldwide (IDF, 2015) and 12 million people in Brazil. The diabetes mellitus type 2 (DM2) being the most prevalent (90\%) (SBD, 2015).

DM causes macro and microvascular complications resulting in clinical, financial and social consequences for the patient and the health system (Pereira, Nogueira, Silva, 2015; Silva et al., 2003). Cezaretto et al. (2016) state that a multidisciplinary psychoeducational approach is able to reduce patients' cardiometabolic risks, being a viable strategy for adopting a healthy lifestyle in the long term (Cezaretto et al., 2016).

It should be noted that the direct and indirect costs related to DM increase with time (Henriksson, Agardh, Berne, 2003). In this way, health services need to deal with ever-increasing costs in contrast to scarce

*Correspondence: A. C. O. Gonçalves. Campus Centro-Oeste Dona Lindu, Faculdade de Farmácia, Federal de São João Del-Rei. Telephone: +55 37 3221-1402. E-mail: aco_goncalves@yahoo.com.br. resources (Guidoni et al., 2009). It is known that the onset of complications related to DM increases the cost of treatment and it is also known that medication makes up $48.2 \%$ of the direct costs of DM treatment (Bahia et al., 2011). Pharmacoeconomics is a component of the economic evaluation of health services that supports decision-making and allocation of resources related to pharmaceutical services/products (ISPOR, 1986).

In order for management to be able to use the results obtained from pharmacoeconomic studies, it is important to know the direct, indirect and intangible costs involved in the costing system of its activities. In a study conducted by Franco et al. (2013), 95.5\% of public agents (accountants and financial sector employees) interviewed in Paraná consider it very important that a cost system be adopted in public services, however, $32.8 \%$ say they do not know the factors that influence the costs of their activities, while $43.3 \%$ consider that cost system information has been useful for decision-making by sector managers and leaders (Franco et al., 2013).

In Brazil, data regarding the cost of treatment of a patient with DM and its complications are still scarce (Borges et al., 2011). The absence of this consensus in 
the literature makes it difficult to analyze costing and cost projections in pharmacoeconomic studies. In this sense, the present study seeks to estimate the vision of public health service managers, and DM specialists, regarding financial investment for the treatment of patients with DM2, relating these investments to the patient's glycemic control from the point of view of the SUS. In this perspective it is important to emphasize that this study does not assess the cost of DM treatment, but rather, what financial contribution health services management is willing to make in order to achieve the patient's glycemic control.

\section{METHOD}

This is a methodological study carried out from November 2015 to April 2016, in which the Delphi Technique (Helmer, Dakley, 1963) was used to estimate the financial value that should be invested in the treatment of a patient with DM2, according to the values of glycated hemoglobin (A1c). The Delphi technique is a methodology recommended by the Ministry of Health that takes into account the opinion of experts on a certain subject when there is no unanimity of opinion due to the lack of scientific evidence, or when the information is contradictory (Brasil, 2013; Revorêdo et al., 2015).

To estimate these data, a questionnaire was applied to a team of judges composed of managers of the health service of a municipality in the center-west of Minas Gerais state (Municipal Secretary, Finance Director, Director of Health Care, Pharmaceutical Assistance Management, and DM and Systemic Arterial Hypertension Management), which deal directly with the application of resources and with the implementation and evaluation of DM related routines. Specialists working with DM patients were also integrated into the team of judges. For the selection of specialists, the following criteria were considered: specialist with an email address available for contact, and belonging to the research centers that had a partnership with the team of researchers and/or member of the work team of the municipality conducting the research. Physicians, nurses, nutritionists, physiotherapists, psychologists, and pharmacists from the states of Minas Gerais, São Paulo, Paraná and Santa Catarina were invited. Managers and specialists composed the team of judges who were supposed to answer "how much would they be willing to invest (value/patient/year) for a patient to achieve a range of $\mathrm{A} 1 \mathrm{c}(<7 \% ; 7.1-8 \% ; 8.1-9 \%$; $9.1-10 \% ; 10.1-11 \% ; 11.1-12 \% ;>12 \%) "$. To support this response, were presented data from the literature regarding the costs of DM and complications, and data of the economy provided by the glycemic control of the patient. The questionnaire was previously analyzed by five DM specialists for content evaluation.

According to Wright and Giovinazzo (2000) a 50\% abstention is expected in the first round and $30 \%$ in the second round of evaluation. Due to the high abstention rate, it is recommended that a large number of people be invited to participate in the team of judges (Revorêdo et al., 2015; Scarparo et al., 2012), therefore, considering the research group's prior experiences, all managers and specialists who met the established criteria were invited to integrate into the team of judges. The questionnaire was sent by email or personally handed to the judges. The team of judges assessed whether the questionnaires had been answered in the correct way and, in case of inconsistency, the judge was notified. If the mistake remained after three tries, the questionnaire was excluded. After the first round of questions, a compilation containing the average, median, minimum, and maximum was resent to each judge that could assess whether their previous answer would be modified or maintained according to the panel of specialists. The answers were considered valid when a concordance of $80 \%$ was obtained considering the answers of all the judges. The concordance was calculated by means of the total answers of all the researchers and the total of modified answers after each round (Figure 1). The normality of the data was evaluated using the Kolmogorov Smirnov test.

The monetary amounts presented in the results expressed in dollars were converted using the quotation on April 30, 2016 (R\$3.451).

\section{RESULTS AND DISCUSSION}

The invitation to respond to the questionnaire was sent to six managers and 64 specialists via e-mail. Five managers and 20 specialists responded (64\% abstention). The questionnaires were delivered personally to judges from the state of Minas Gerais and the city of Ribeirão Preto (SP) and sent via e-mail to judges from the other states (São Paulo, Santa Catarina and Paraná). Four managers and 17 specialists returned the completed questionnaire (16\% abstention). A questionnaire was excluded for noncompliance with the response guidelines. It is observed that the abstention rate was higher than expected in the first round of questions, however, in the second round this index is lower (Wright, Giovinazzo, 2000). It is expected that the high abstention of the first round will not impact the results. In the second round, two managers and a specialist made changes to the answers. 


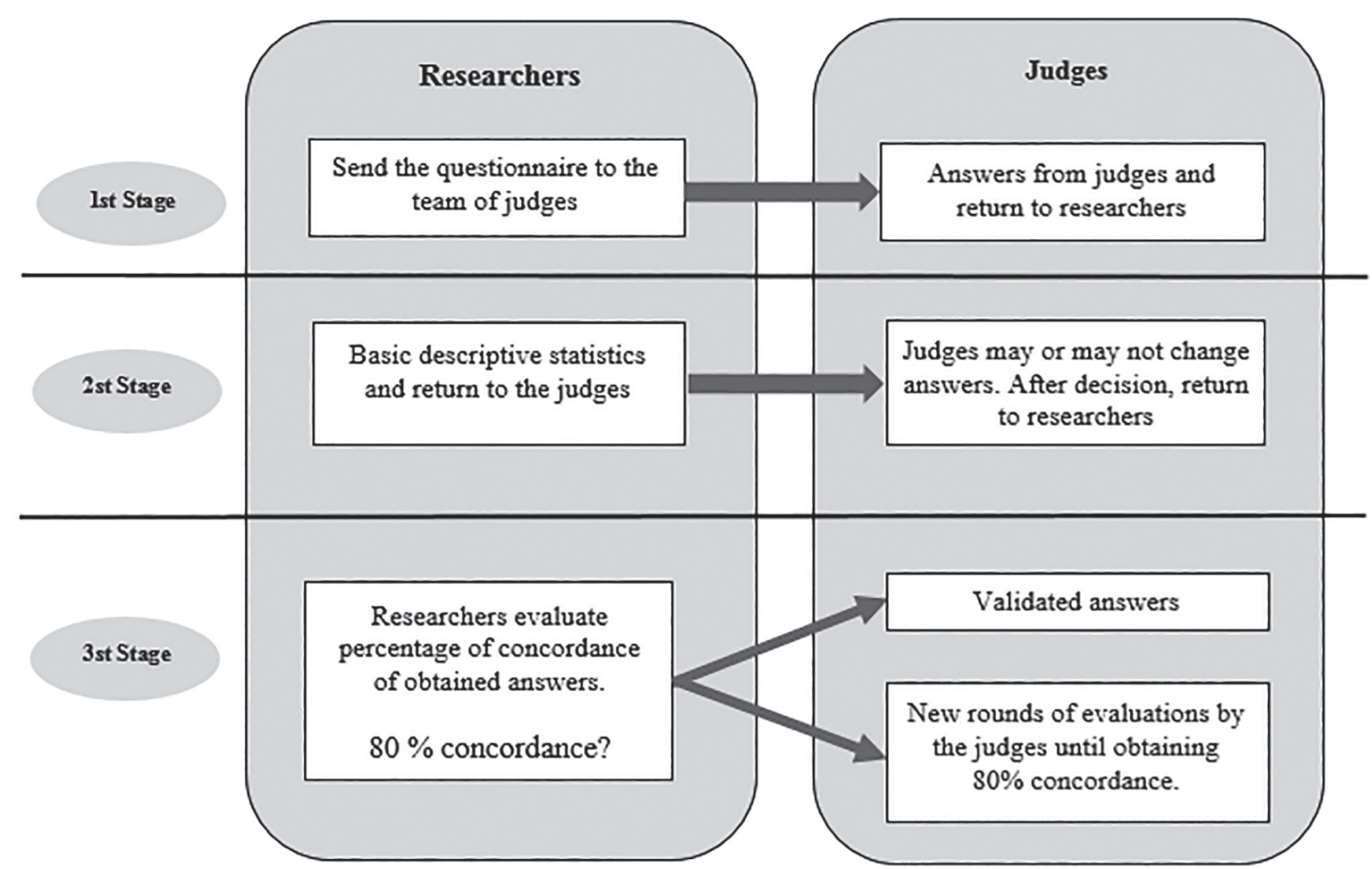

FIGURE 1 - Description of the evaluation stages of the judges in the Delphi technique. Source: Prepared by the author. Adapted from Sousa and Turrini, 2012 (16). Legend: DM2 - Diabetes Mellitus Type 2.

The agreement was $83.3 \%$ and the answers were validated by the Delphi technique. The medians of the answers make up the final result presented below.

According to the consensus of experts, US\$2,419.06 should be invested annually (value/patient/year) so that the patient achieves $\mathrm{A} 1 \mathrm{c}<7 \%$. The value of the investment decreases as the value of A $1 \mathrm{c}$ increases, as can be seen in Table I.

TABLE I - Annual investment of the health service management according to glycemic control of the patient with diabetes mellitus type 2 (DM2), after consensus of specialists. Source: Prepared by the author. $\mathrm{N}=21,2015-2016$

\begin{tabular}{cc}
\hline A1c (\%) & Median (min. - max.) (U\$) \\
\hline$<7$ & $2,419.06(1,159.15-3,767.24)$ \\
$7.1-8$ & $2,236.73(1,014.26-3,152.89)$ \\
$8.1-9$ & $1,683.67(869.36-2,680.54)$ \\
$9.1-10$ & $1,263.48(145.71-2,405.24)$ \\
$10.1-11$ & $744.75(145.71-2,086.47)$ \\
$11.1-12$ & $667.67(145.71-3,152.89)$ \\
$>12$ & $595.22(145.71-3,783.47)$ \\
\hline
\end{tabular}

Legend: A1c - glycated hemoglobin. Min. - minimum. Max. - maximum
In a survey conducted by Bahia et al. (2011) in eight Brazilian cities, considering different levels of complexity, the annual cost of a patient with DM for the health service is US\$2,108.00. Henriksson, Agardh and Berne (2000) concluded that patients with associated microvascular and macrovascular complications may have treatment costs tripled when compared to patients without these complications. Compared with the present study, it is presumed that the prevention of complications is the main objective of the managers, since there is an intention to place the largest volume of financial resources for the patient to achieve glycemic control (A1c $<7 \%$ ).

In a Brazilian study by Obreli-Neto et al. (2015), it was verified that the reduction of $0.7 \%$ in A $1 \mathrm{c}$ provides a saving of US\$ 660.00 per patient per year.

A study by Arredondo and Icaza (2011) in Mexico predicted a $33 \%$ increase over three years in direct and indirect costs related to DM, and the modification of risk factors and care models for DM treatment is the only alternative for these costs not to become unsustainable for health services (Arredondo, Icaza, 2011).

Another recent study that assessed the DM cost for 2015 in Latin America and the Caribbean found a value of 123 billion dollars/year, with resources mostly destined to the treatment of complications and with an estimated 
per capita cost between US\$ $1,088.00$ and US\$ $1,818.00$ (Barcelo et al., 2015).

The American Diabetes Association survey estimated a 245 million/year cost, with a US\$ 7,900.00 per capita cost, and with $61 \%$ of the resources being destined to the payment of hospitalizations and of drugs related to DM complications (ADA, 2013). A systematic review carried out in the Netherlands estimated that the direct and indirect costs of DM treatment in 2016 was 6.8 billion euros, and that about 4 billion of that amount was destined to the treatment and loss of productivity related to DM complications (Peters et al., 2017). A recently performed systematic review which considered the costs involved in DM treatment concluded that prevention, early DM detection and good quality of the services provided to the patient are essential for the reduction in the occurrence of complications (Mustapha et al., 2017). Considering the afore-mentioned, and the findings of this study, it is important to highlight that the greater the number of complications, the higher the cost of treatment and the less managers will be willing to invest. This stresses the need for DM-complication prevention strategies.

Observing the results of the present study, it is noted that the values suggested by the team of judges are in accordance with the per capita cost values practiced in Brazil. However, they are higher than the Latin American and Caribbean values and lower than the USA values. It is also noted that, when the possibility of investing is stratified according to the A1c values, prevention of complications is the main goal of the judges, as the intention is to allot more resources so that patients can achieve glycemic control (A1c $\leq 7 \%)$. This fact corroborates the literature, since complications related to DM consume a considerable amount of financial resources. Thus, preventing complications from arising is consequently the rational way to apply and optimize the resources available.

This scenario highlights a paradox for the healthcare system, as the need for resource allotment for DM prevention is understood. However, it is necessary to deal with a reality in which patients struck by the disease show complications and require large sums of money for their treatment. From the point of view of equity, resources are allotted in order best to serve those who are most in need; nevertheless, from the point of view of integrality, it is necessary to implement health promotion and worsening prevention actions so that all healthcare needs can be met (Brasil, 1990).

This is why it is necessary for healthcare services to constantly seek more efficient alternatives for glycemic control of DM patients, since preventing complications provides the patient with better quality of life.

The use of quality databases and information in the management of health services is a necessity reinforced by several authors (Drachler et al., 2003; Bittar et al., 2009; Lima et al., 2009). Guidoni and collaborators (2012) used database searches to trace the pharmacological profile of patients with DM in Ribeirão Preto (SP, Brazil). Data and information analyzes were used in the creation of an epidemiological and economic profile for patients in renal replacement therapy (Szuster et al., 2009). Berretta, Lacerda, Calvo (2011) proposes an evaluation model of municipal management for health planning and puts information management as one of the main axes in assessing the quality of management. during the development of this model, among the participating municipalities, the satisfaction with updating the databases was higher than $70 \%$, however, in the final result of the evaluation, only $23.6 \%$. The management for health planning was considered effective in $23.6 \%$.

In this sense the result of this study becomes innovative, as it correlates willingness to invest financially, and glycemic control capability. This provides reflection about the implementation of new health technologies, thus highlighting the need to assess the costs and benefits of adopting a healthcare technology or process to be offered at a healthcare unit, something that rarely happens in the Brazilian healthcare system.

\section{ACKNOWLEDGEMENTS}

We thank the Municipal Health Department of Divinópolis and all the specialists who participated in the team of judges of this study. We thank the University of São Paulo (USP) and the Research Group on epidemiology and evaluation of new technologies in health through partnership, of Federal University of São João Del-Rei (UFSJ).

\section{REFERENCES}

American Diabetes Association (ADA). Standards of Medical Care in Diabetes 2016. Diabetes Care. EUA; 2016.

American Diabetes Association (ADA). Standards of Medical Care in Diabetes 2013. Diabetes Care. EUA; 2013.

Arredondo A, Icaza E. Costos de la Diabetes en America Latina: Evidencias del caso Mexicano. Value Health. 2011;14(5 Suppl 1):85-88. 
Bahia LR, Araujo DV, Schaan BD, Dib SA, Negrato CA, Leão MPS, Ramos AJS, Forti AC, Gomes MB, Foss MC, Monteiro RA, Sartorelli D, Franco LJ. The costs of Type 2 Diabetes Mellitus outpatient care in the Brazilian Public Health System. Value Health. 2011;14(5 Suppl 1):137-140.

Barcelo A, Arredondo A, Gordillo-Tobar A, Segovia J, Qiang A. The cost of diabetes in Latin America and the Caribbean in 2015: Evidence for decision and policy makers. J Glob Health. 2017;7(2):020410.

Berretta IQ, Lacerda JT, Calvo MCM. Modelo de avaliação da gestão municipal para o planejamento em saúde. Cad Saúde Públ. 2011;27(11):2143-2154.

Bittar TO, Meneghim MC, Mialhe FL, Pereira AC, Fornazari DH. O Sistema de Informação da Atenção Básica como ferramenta da gestão em saúde. RFO. 2009;14(1):77-81.

Borges APS, Guidoni CM, Freitas O, Pereira LRL. Economic evaluation of outpatients with type 2 diabetes mellitus assisted by a pharmaceutical care service. Arq Bras Endocrinol Metab 2011;55(9):686-691.

Brasil. Ministério da Saúde. Diretrizes Metodológicas: Elaboração de Estudos para Avaliação de Equipamentos médicoassistenciais. Brasília: MS; 2013.

BRASIL. Ministério da Saúde. Lei no ${ }^{\circ}$ 8.080, de 19 de setembro de 1990. Disponível em: < http://www.planalto.gov.br/ ccivil_03/leis/L8080.htm>.

Cezaretto A, Barros CR, Almeida-Pititto B, Siqueira-Catania A, Monfort-Pires M, Folchetti LG, Ferreira SR. Lifestyle intervention using the psychoeducational approach is associated with greater cardiometabolic benefits and retention of individuals with worse health status. Arch Endocrinol Metab. 2017;61(1):36-44.

Drachler ML, Côrtes SMV, Castro JD, Leite JCC. Proposta de metodologia para selecionar indicadores de desigualdade em saúde visando definir prioridades de políticas públicas no Brasil. Ciênc Saúde Coletiva. 2003;8(2):461-470.

Franco LMG, Nascimento C, Santos MM, Espejo B, Voese SB. Sistemas de custos: importância, viabilidade e utilidade na concepção dos agentes públicos do estado do Paraná (Brasil). Rev Educ Pesq Contabil. 2013;7(2):167-183.
Guidoni CM, Borges AP, Freitas OD, Pereira LR. Prescription patterns for diabetes mellitus and therapeutic implications: a population-based analysis. Arq Bras Endocrinol Metabol. 2012;56(2):120-7.

Guidoni CM, Oliveira CMX, Freitas O, Pereira LRL. Assistência ao diabetes no Sistema Único de Saúde: análise do modelo atual. Brazilian Journal of Pharmaceutical Sciences. 2009;45(1):3748.

Helmer O, Dakley N. Uma aplicação experimental do Método Delphi para o uso de especialistas. Manag Sci. 1963;9(3):458467.

Henriksson F, Agardh C, Berne C. Direct medical costs for patients with type 2 diabetes in Sweden. J Intern Med. 2000;248(5):387-396.

International Diabetes Federation. Diabetes Atlas. 4th ed. Brussels: International Diabetes Federation; 2015.

International Society for Pharmacoeconomics and Outcomes Research. [homepage na internet] ISPOR. 1986. [Acesso em 11 nov 2016]. Disponível em: http://www.ispor.org/publications/ VIHRI/index.asp.

Lima CRA, Schramm JMA, Coeli CM, Silva MEM. Revisão das dimensões de qualidade dos dados e métodos aplicados na avaliação dos sistemas de informação em saúde. Cad Saúde Públ. 2009;25(10):2095-2109.

Mustapha FI, Azmi S, Manaf MRA, Hussein Z, Mahir NJN, Ismail F, Aizuddin AN, Goh A. What are the direct medical costs of managing Type 2 Diabetes Mellitus in Malaysia? Med J Malaysia. 2017;72(5):271-277.

Obreli-Neto PR, Guidoni CM, Baldoni AO, Pilger D, CruciolSouza JM, Gaeti-Franco WP, Cuman RK. Effect of a 36-month pharmaceutical care program onpharmacotherapy adherence in elderly diabetic and hypertensive patients. International J Clin Pharm. 2015;33(4):642-649.

Pereira DS, Nogueira JAD, Silva CAB. Qualidade de vida e situação de saúde de idosos: um estudo de base populacional no Sertão Central do Ceará. Rev Bras Geriatr Gerontol. 2015;18(4):893-908.

Peters ML, Huisman EL, Schoonen M, Wolffenbuttel BHR. The current total economic burden of diabetes mellitus in the Netherlands. Neth J Med. 2017;75(7):280-297. 
Revorêdo LS, Maia RS, Torres GV, Maia EMC. O uso da técnica de Delphi em saúde: uma revisão integrativa de estudos brasileiros. Arq Ciênc Saúde. 2015;22(2):16-21.

Scarparo AF, Laus AM, Azevedo ALCS, Freitas MRI, Gabriel CS, Chaves LDP. Reflexões sobre o uso da técnica Delphi em pesquisas na enfermagem. Rev Rene. 2012;13(1):242-251.

Silva I, Pais-Ribeiro J, Cardoso H, Ramos H, Carvalhosa SF, Dias S, Gonçalves A. Efeitos do apoio social na qualidade de vida, controle metabólico e desenvolvimento de complicações crónicas em indivíduos com Diabetes. Psicol Saúde Doenças. 2003;4(1):21-33.

Sociedade Brasileira de Diabetes. Diretrizes da Sociedade Brasileira de Diabetes: 2014-2015. São Paulo: SBD; 2015.
Sousa CS, Turrini RNT. Validação de constructo de tecnologia educativa para pacientes mediante aplicação da técnica Delphi. Acta Paul Enferm. 2012;25(6):990-996.

Szuster DAC, Silva GM, Andrade EIG, Acúrcio FA, Caiaffa WT, Gomes IC, et al. Potencialidades do uso de bancos de dados para informação em saúde: o caso das Terapias Renais Substitutivas (TRS) - morbidade e mortalidade dos pacientes em TRS. Rev Med Minas Gerais. 2009;19(4):308-316.

Wright JTC, Giovinazzo RA. Delphi - uma ferramenta de apoio ao planejamento prospectivo. Cad Pesq Adm. 2000;1(12):54-65.

Received for publication on $04^{\text {th }}$ April 2017 Accepted for publication on $04^{\text {th }}$ May 2018 